Warm up

\title{
Best foot forward
}

\section{P McCrory}

A newspaper article from Australia last weekend described a man who collects old thongs off the beach. Now a word in the ear of those of you who know the term thong only as an item of uncomfortable female underwear can rest easy. In Australia, it refers to a type of rubber footwear worn on beaches. In Queensland, and other northern states of Australia, it may be considered an acceptable item of apparel on formal occasions. What was remarkable about this thong enthusiast or thongologist is that he had acquired almost 5000 discarded thongs over the past few years, which he has nailed to his front fence. Why would you bother-one may well ask-but I would imagine a colourful rubber thong fence may well look more attractive to potential buyers than piles of unsightly beer bottles. Mind you, some folks in the interior of this country build whole houses out of beer bottles. But I digress. I was struck not just by this aberrant behaviour but rather the gent's throwaway comment that $80 \%$ of the discarded thongs were for the left foot. This is surely worth a $\mathrm{PhD}$ to some sports physician. Is there some subtle universal truth about left handed thongs living on beaches, or do the unaccounted for right ones finish up with all the missing pens and other items that vanish on a daily basis from our office and pockets? I am sure the late (and great) Douglas Adams could have advanced a theory to explain this phenomenon. Perhaps there is a man with 5000 right thongs nailed to a fence somewhere. He may well be in an institution or even in another dimension but wherever the thongs may have gone, we desperately need some further work on this area.

In America it is easily explained. Aliens. After all, 2.1 million US citizens claim to have been abducted by aliens at some point in their lives so what's a few thongs along the way. In Australia, these alien abductions seem to bypass us. Perhaps if we had more talk shows, we may get more alien interest. Where is Jerry Springer when you need him?

But it highlights why research is such a funny business. In sports medicine, we have the data. We have access to teams and other populations who have injuries or need interventions to improve their health. We have the people. There are physios, doctors, massage therapists, sports scientists, and every conceivable form of assistance available yet we struggle to turn this clinical experience into a body of research evidence. We have the research questions. Every day we attempt to provide advice to athletes that needs to be evidence based yet remains firmly anecdotal.

Asking a simple question that can be answered is important. I think Einstein made a similar comment and didn't he do well for an ex-patent office worker from Vienna. In the Australasian College of Sports Physicians, all registrars in training are required to publish a piece of original research to be admitted to the Fellowship. It has been a huge boon to sports medicine with a constant stream of publications arising through this process. It is clear though that clinicians in whatever discipline need to be mentored through this process to achieve the outcome desired. Clinicians in isolation make poor researchers, yet with the appropriate direction they can be brilliant. Look at the examples from our own journal's editorial board-Roald Bahr in Norway, Karim Khan in Canada, Per Holmig in Denmark, Karen Johnston in Montreal, Hakan Alfredson in Sweden, and the list goes on and on. Clinically trained sports medicine physicians who obtain research skills and then can lead programmes and increase research capacity within their area. The future looks bright as more quality researchers come on stream. Now is not the time to rest, we need to accelerate this process so that we can take our rightful place among the other medical specialties confident in our knowledge base and looking forward.

BrJ Sports Med 2002;36:391 


\section{Expression of concern about content of which Dr Paul McCrory is a single author}

This paper is authored by Dr Paul McCrory. During 2021 and 2022 there was an investigation by BJSM and BMJ which found that some of his work was the product of publication misconduct. Such misconduct includes plagiarism, duplicate publication, misquotation and misrepresentation in publications in respect of which he was listed as the sole author. ${ }^{1}$ We are placing a notice to readers on all content in relation to which he is identified as the sole author to alert them to the conclusions of our investigation.

(C) Author(s) (or their employer(s)) 2022. No commercial re-use. See rights and permissions. Published by BMJ.

Br J Sports Med 2022;0:1. doi:10.1136/bjsports-2022-106408eoc

D) Check for updates

\section{REFERENCE}

1 Macdonald H, Ragavooloo S, Abbasi K. Update into the investigation of former BJSM editor-in-chief Paul McCrory. Br I Sports Med 2022. 